\title{
COMPARATIVE STUDY OF SOME SEMI-DRY ARABIAN DATE PALM CULTIVARS GROWN IN MOUNOFIA GOVERNORATE
}

\author{
SAMIA S. HOSNY
}

Tropical fruits Res. Dep., Hort. Res. Inst. ARC, Giza, Egypt

dr.samiasalah@yahoo.com

(Manuscript received 27 July 2016)

\begin{abstract}
$\mathrm{T}$ his study was carried out through 2014 and 2015 to study the performance of four Arabian semi-dry date cultivars produced through tissue culture namely: "Zahdi", "Sakai", "Medjool", and "Khalas" grown in El-Khatatba region, Mounofia governorate, Egypt in comparison with the commercial semi-dry cv. "Sewy" (as a local cultivar). The study involved the flowed assessed parameters, dates of the first and last spathe emergence and bursting, fruit set and fruit retention \%, date of harvest, number of bunches/palm and average yield per palm, as well as physical and chemical properties of fruits. Emergence and bursting of spathe of "Medjool" and "Khalas"occurred early, followed by "Sewy" and "Zahdi" while "Sakai"cv. came last. Harvesting of all tested cultivars was done on the first week of October. Regarding the yield, highest yield was obtained from"Madjool" palms in comparison with other tested cvs. followed by "Sewy" and "Zahdi" while it was the lowest with "Sakai" and "Khalas". Also, "Sewy" and"Madjool" palms produced the highest number of bunches /palm while the lowest number of bunches/palm was recorded by "Sakai". With regard to fruit set and fruit retention $\%$ "Medjool" cv. attained the highest percentage of fruit set and fruit retention\% while "Khalas" was the lowest cultivar in this respect. Concerning physical properties, data proved the superiority of "Medjool"fruits in weight, dimensions and flesh/fruit weight\% meanwhile"Sakai" fruits were the opposite. As for chemical properties, moisture content in fruits was the highest in "Sakai" fruits and lowest in "Khalas". Data proved the superiority of "Sakai" and "Madjool" in T.S.S\% and total sugars content. Results showed also that most of these sugars were reducing sugars. Regarding tannins content, the differences between tested cultivars did not reach the level of significance. General evaluation revealed that "Madjool"cv. proved to be the superior $\mathrm{cv}$. in yield and fruit quality among all the studied cvs., followed by "Sewy" cultivar which ranked the second in both total score units of yield and fruit quality, while "Khalas" and "Sakai"cvs.had the lowest score in general evaluation due to receiving the lowest score units specified for yield. However, fruit quality of these cvs.was lower than of the standard cultivar ("Sewy"). In addition," Zahdi" cv. seemed to be of great yield but fruit quality was less than that of "Sewy"cv. Thus, one can conclude that"Medjool" and
\end{abstract}




\begin{abstract}
"Sewy" cvs. proved to be the superior cvs. in yield and fruit quality. However "Zahdi" cv. seemed to be of great yield but fruit quality was lower than the standard cv. "Sewy". On the other hand,"Sakai "cv. showed lower palm yield but fruit quality was reasonable for consumer, but, it was generally lower than of "Sewy" cultivar.
\end{abstract}

Key words: Semi-dry date palm -Numerical evaluation

\title{
INTRODUCTION
}

Date palm grows successfully throughout Egypt from the relatively cool coast of Mediterranean sea (lat. $31^{\circ} .30^{\prime} \mathrm{N}$ ) up to the burning heat of Asswan governorate (lat. $22^{\circ} \mathrm{N}$ ). Cultivars naturally confine themselves to certain localities where they do better elsewhere. For instance, on the Mediterranean shore we find soft dates cultivars, at middle Egypt the semi dry dates cultivars predominate, while Siwa, Baharia, Farafra, Dakhla and kharga Oasis are occupied mostly with "Sewy": (semi dry dates), Asswan is devoted to the dry cultivars (Brown and Bahgat, 1938). The prospective date grower should give careful attention to the selection of cultivars likely to succeed in his locality; climatic adaptations are of primary importance (Nixon, 1978). In Egypt there are only three cultivars that belong to semi dry dates group ("Sewy", "Amry"and "Aglany"). Semi dry dates cultivars are considered very important to date industry in recent years. The decrement of superior cultivars number from this group is a big problem. Recently the Ministry of Agriculture and date grower have imported some Arabian semi-dry date cultivars produced through tissue culture; these cultivars are grown now at different region. Several papers studied the behavior of some of these cultivars (Salem \&Hamdy 1993; Ahmed et al., 1996; Sayed, 1999 and Gadalla 2013) and the effect of agro climatic conditions on quality of date fruit and on thier ripening time (Abdalla et al 1991; Khan et al.,2008 and Iqbal et al., 2011). "Medjool" merits a more detailed account than some other varieties; it has become a very important variety to the date industry in recent years and its history is somewhat unusual."Medjool" is the most desirable because of its large size, soft flesh, excellent taste, and attractive appearance. Zaid, (2002). on the other hand "Sewy" date cultivar is one of the most important cultivars of semi-dry dates group and to demanded in local and foreign markets for its good quality.

The aim of this present study was to compare the performance of four Arabian semi-dry date cultivars produced through tissue culture namely: "Zahdi", "Sakai", "Medjool", and "Khalas"in comparison with the commercial cv. "Sewy" (local cultivar), all grown in El-Khatatba region, Mounofia governorate, Egypt. 


\section{MATERIALS AND METHODS}

The present study was conducted through two growing seasons 2014 and 2015 to compare of four Arabian date palm cultivars namely "Medjool", "Zahdi", "Sakai" and "khalas"as well as the local cultivars "Sewy" as a standard all grown under El-Khatatba region condition at Mounofia Governorate (latitude $30^{\circ} \mathrm{N}$, longitude $31^{\circ} \mathrm{W}$ ). Average maximum temperatures as well as relative humidity percentage for El-Khatatba region Mounofia governorate during 2014 \&2015 years are shown in the following Table.

Table 1. Maximum and minimum temperatures and relative humidity for El-Khatatba region during two experimental seasons (2014 - 2015).

\begin{tabular}{|c|c|c|c|c|c|c|}
\hline \multirow{3}{*}{ Month } & \multicolumn{3}{|c|}{2014} & \multicolumn{3}{|c|}{2015} \\
\hline & \multicolumn{2}{|c|}{ Temperature $\mathrm{C}^{\circ}$} & \multirow{2}{*}{$\begin{array}{l}\text { Relative } \\
\text { humidity }\end{array}$} & \multicolumn{2}{|c|}{ Temperature $\mathrm{C}^{\circ}$} & \multirow{2}{*}{$\begin{array}{l}\text { Relative } \\
\text { humidity }\end{array}$} \\
\hline & Max. & Min. & & Max. & Min. & \\
\hline May & 32 & 17.0 & 51 & 38.7 & 22.9 & 50 \\
\hline June & 33.5 & 21.1 & 55 & 41.5 & 25.1 & 54 \\
\hline July & 36.9 & 22.4 & 61 & 41.6 & 24.6 & 62 \\
\hline August & 34.2 & 20.0 & 60 & 40.9 & 24.0 & 63 \\
\hline Sept. & 33.1 & 16.6 & 59 & 37.8 & 22.9 & 58 \\
\hline Octo. & 30.5 & 15.5 & 47 & 35.9 & 20.3 & 48 \\
\hline
\end{tabular}

* Source Central Laboratory for Agricultural Climate (CLAC) A.R.E.

The Five tested cultivars belong to the yellow color type of semi dry date's group (Gadalla, 2013). Each cv. was represented by five palms (i.e. five replicates) and palms of all the studied cvs. were in full production stage, nearly at the same age (about 15 years old) and received the same horticultural practices and pollinated within two days after spathe bursting by using pollen grains from the same parent in both seasons. The following indices were studied and recorded:

Spathe emergence and bursting: Dates of commencement and ending of spathes emergence and bursting.

Yield and bunch characteristics: the harvest took place when the fruits reached to the first tamr stage, the following data were recorded: date of harvest, number of bunches per palm and yield per palm.

Fruit set \%: number of set fruits per stalk was recorded one month after pollination; 25 attached stalks on 5 bunches per palm were used for this purpose. The percentage of fruit set was calculated using the following equation:

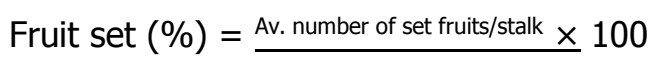


Fruit retention \%: number of retained fruits/ stalk was recorded at harvesting time; 25stalk on 5 bunches per palm were used for this purpose the percentage of fruit retention was calculated using the following equation:

Fruit retention $(\%)=$ Av. number of retained fruits/stalk $\times 100$

Av. number of set- fruits/stalk

Physical and chemical properties of fruits: representative fruit sample 5 fruits collected at harvesting time of each replicate (from each palm). Fruit evaluation included fruit weight and dimensions (axial and equatorial diameter), seed weight and flesh percentage. Moisture and total soluble solids (T.S.S) \% content were determined according to the method described in the A.O.A.C. (1995). Total, reducing and non reducing sugars content were determined according to the method of Lane and Eynon as described in the A.O.A.C. (1995). Also; tannins content was determined by using standard curve of tannic acid and expressed as $\mathrm{mg}$ tannins/g. f. wt. as described by Resenabatt and Pelluso (1941).

General evaluation of the tested Arabian cultivars: the final evaluation of any tested cultivar was calculated on the basis of 100 units which were shared between palm yield (30 units) and fruit quality (70 units) (Abdalla et al, 1995 and Gadalla, 2012) the latter units were divided on the basis of 15 units for both of fruit weight, flesh \%, total sugars and 10 units for T.S.S., beside 5 units for both of fruit length, fruit diameter and tannins content, as shown in table (6). Each palm that gave the best results for any characteristics took the full mark specified for this property, while each of the other tested palms took lower units equal to their quality.

Statistical analysis: five replicates (i.e. five palms) were used per cultivar, arranged in a complete randomized design and statistically analyzed to detect variation according to (Snedecor and Cochran, 1980). New least significant differences (New L.S.D. at 0.05) were used to compare between averages (Waller \&Duncan, 1969).

\section{RESULTS AND DISCUSSION}

\section{Dates of spathe emergence and bursting and harvesting:}

Data in Table (2) showed enormous variations between tested date palm cultivars in dates of emergence and bursting of spathe and harvesting. In both seasons emergence of the first and last spathe occurred in-between 10/2 to 8/3 for "Medjool" cv. followed by "Khalas" (15/2 to 10/3), "Sewy" (20/2 to 12/3), and "Zahdi"(20/2 to 10/3) and at last "Sakai" cv. (5 to 25/3). Regarding spathe bursting date, data also show the same trends as observed in spathe emergence, i.e. the sequence of the spathe bursting in both seasons was as follows:" Medjool" and"Khalas" (from 25/2 to 15/3), 
"Sewy" (from 5 to 25/3), "Zahdi" (from 10 to 25/3) and at last "Sakai" (from 15/3 to 5/4). In other words; the obtained data suggest that under conditions of El-Khatatba region, spathe emergence and bursting on palms of "Medjool" and "Khalas" cvs. occurred early while "Sewy" and "Zahdi"cvs. were done 5-13 days later meanwhile "Sakai"cv. was the lowest in this respect. Brown and Bahgat, (1938) stated that in lower and middle Egypt the female date palms usually commence flowering in the beginning of March. However, the same authors observed that the local date cvs. that are growing side by side under the same conditions, differences between them in spathe emergence are quite clear. Concerning harvesting date, all tested cvs. including standard cv. ("Sewy") were picked at the first week of October in both seasons. The great variations that occurred on emergence and bursting of spathe and harvesting date in most date palm cvs. was supported by the results of Salem \&Hamdy (1993), Abdallaet al. (1995) Sayed (1999), and Gadall (2013). In addition, fruit harvesting depended upon the cultivars and weather conditions (Abou Rekab, 2005).

Table 2. Dates of spathe emergence, spathe bursting and harvesting of some Arabian and local date cultivars grown under of condition of Mounofia government during 2014 and 2015 seasons.

\begin{tabular}{|c|c|c|c|c|c|c|}
\hline \multirow{2}{*}{ Cultivars } & \multicolumn{2}{|c|}{ Date of spathe emergence } & \multicolumn{2}{|c|}{ Date of spathebursting } & \multicolumn{2}{|c|}{ Harvesting date } \\
\cline { 2 - 7 } & 2014 & 2015 & 2014 & 2015 & 2014 & 2015 \\
\hline \multirow{2}{*}{ Zahdi } & $20 / 2$ to $5 / 3$ & $25 / 2$ to $10 / 3$ & $10 / 3$ to $20 / 3$ & $10 / 3$ to $25 / 3$ & $1 / 10$ & $5 / 10$ \\
\hline Sakai & $5 / 3$ to $15 / 3$ & $15 / 3$ to $25 / 3$ & $15 / 3$ to $1 / 4$ & $25 / 3$ to $5 / 4$ & $1 / 10$ & $5 / 10$ \\
\hline Khalas & $15 / 2$ to $25 / 2$ & $20 / 2$ to $1 / 3$ & $25 / 2$ to $10 / 3$ & $5 / 3$ to $15 / 3$ & $1 / 10$ & $5 / 10$ \\
\hline Medjool & $10 / 2$ to $25 / 2$ & $15 / 2$ to $8 / 3$ & $25 / 2$ to $10 / 3$ & $25 / 2$ to $15 / 3$ & $1 / 10$ & $5 / 10$ \\
\hline Sewy & $20 / 2$ to $1 / 3$ & $25 / 2$ to $12 / 3$ & $5 / 3$ to $15 / 3$ & $10 / 3$ to $25 / 3$ & $1 / 10$ & $5 / 10$ \\
\hline
\end{tabular}

\section{Number of bunches / palm:}

Data in Table (3) show significant differences in number of bunches / palm between the tested cvs., the average of the two years show that "Sewy", "Medjool" and "Zahdi" palms produced the highest number of bunches (11.84, 11.33 and 10.84 bunches /palm, respectively with no significant differences between them, followed by "Khalas" ( 9.00 bunches /palm) in comparison with "Sakai" palms which produced the lowest number of bunches (6.67 bunches /palm).

\section{Yield per palm:}

From data of yield / palm presented in Table (3) reveal the same trends as that observed on number of bunches / palm, i.e. palms of "Medjool" produced the highest yield which amount to an average of $119 \mathrm{kgs} /$ palm, followed by "Sewy" (about $112 \mathrm{kgs}$ ) 
and "Zahdi" (about 110kgs), then by cultivars "Khalas" and "Sakai"which produced the least yield per palm (about 63 and 47kgs, respectively).( Increased yield/palm may be due to increased number of bunches / palm, number of retained fruits to harvest and fruit weight which ultimately affected the yield / palm positively as compared to other cultivars). These results are in harmony with those reported by Salem \& Hamdy (1993), Ahmed et al (1996) and Sayed(1999) on some Saudi and Iraqi date palm cultivars, Gadall (2013) on some Arabian date palm cultivars including "Zahdi", "Madjool", "Khalas" and "Sakai" as well as "Sewy" as local cultivar, in addition, Abdalla et al (1995) on some local date cvs. who stated that there was a wide and great variation in fruiting behavior of most date palm cvs.

\section{Fruit set and Fruit retention \%:}

Data in Table (3) revealed that there are a wide variation in fruit set and fruit retention \% between the different Arabian date palm cultivars under El-Khatataba region conditions. The average values of the two seasons show that "Medjool" cv. attained uppermost fruit set and fruit retention percentage (84.55 and $82.12 \%$, respectively). "Sewy"cv. came the second order (80.95 and $76.00 \%$ ), in comparison with"Khalas" which showed the lowest percentage (57.33\% for fruit set and $47.35 \%$ for fruit retention), while "Zahdi" and "Sakai"cvs, were in between in this respect. The obtained results are generally in line with those found by Salam \&Hamdy (1993) and Gadalla (2013), who found that fruit set \% of "Sewy";"Madjool";"Zahdi" and "Khalas" were $82.8,82.1,67.2$, and $56.9 \%$, respectively.

Table 3. Yield parameters, fruit set and fruit retention \% of some Arabian and local date cultivars grown under of condition of Mounofia government during 2014 and 2015 seasons.

\begin{tabular}{|l|l|l|l|l|l|l|l|l|l|l|l|l|l|}
\hline \multirow{2}{*}{ cultivars } & \multicolumn{3}{|l|}{ Number of bunches/palm } & \multicolumn{2}{|c|}{ Yield / palm(kg) } & \multicolumn{2}{|c|}{ Fruit set \% } & \multicolumn{3}{|c|}{ Fruit retention \% } \\
\cline { 2 - 16 } & 2014 & 2015 & Av. & 2014 & 2015 & Av. & 2014 & 2015 & Av. & 2014 & 2015 & Av. \\
\hline Zahdi & 12.00 & 9.67 & 10.84 & 120.30 & 100.33 & 110.32 & 73.87 & 72.07 & 72.97 & 65.27 & 67.90 & 66.59 \\
\hline Sakai & 7.33 & 6.67 & 6.67 & 43.67 & 50.67 & 47.17 & 77.57 & 76.97 & 77.27 & 71.16 & 71.27 & 71.22 \\
\hline Khalas & 9.00 & 9.00 & 9.00 & 53.33 & 73.67 & 63.50 & 55.43 & 59.23 & 57.33 & 48.70 & 46.00 & 47.35 \\
\hline Medjool & 11.33 & 11.33 & 11.33 & 120.67 & 117.67 & 119.17 & 85.07 & 84.03 & 84.55 & 81.33 & 82.90 & 82.12 \\
\hline Sewy & 12.00 & 11.67 & 11.84 & 100.00 & 124.67 & 112.34 & 80.63 & 81.27 & 80.95 & 78.00 & 74.00 & 76.00 \\
\hline $\begin{array}{l}\text { New L.S.D. } \\
\text { at 0.05 }\end{array}$ & 1.41 & 1.33 & 1.37 & 7.00 & 5.84 & 6.42 & 1.53 & 1.69 & 1.61 & 1.83 & 1.92 & 1.88 \\
\hline
\end{tabular}




\section{Fruit physical properties:}

Data in Table (4) showed that there are significant differences in fruit weight, fruit dimension and flesh weight\% between the tested cvs., the average values of the two seasons show that "Madjool" fruits were superior among the tested cultivars in weight, dimensions and flesh \%, meanwhile "Sakai" fruits were on the opposite. As for fruit weight, could be arranged the tested cvs. descending as follows: "Medjool"(24.20 gms as average of two seasons), "Sewy" (13.27gms), "Khalas" (11.65gms) and "Zahdi" (11.24gms) then fruits of "Sakai" cv. which were the lightest in weight (7.42 gms). Hussein et al. (1976) classified 18 date cvs. grown in Saudi Arabia according to the following system: 1) Fruit weight more than 15 gms. 2) Fruit weight from 10 to 15 gms. 3) Fruit weight less than $10 \mathrm{gms}$. , according to this classification, "Medjool" cv. belongs to the first group, and cvs. "Sewy", "Khalas" and "Zahdi" belong to the second group, while "Sakai" cv. belongs to the third group. The obtained results goes in line with those found by Salem \&Hamdy (1993) who found that under conditions of Upper Egypt fruit weight was $14.14 \mathrm{gms}$. for "Zahdi" and 12.22 gms for "Sewy" cv. However, Sayed (1999) under Minia region conditions, fruit weight of "Sewy" was ranged from 11.0 to $12.4 \mathrm{gms}$. and from 9.5 to $10.5 \mathrm{gms}$ for "Zahdi".

With regards to fruit dimension data in the same Table reveal the same trends as observed on fruit weight, i.e. fruits of "Medjool" were longest and widest diameter $(4.64 \times 2.72 \mathrm{cms})$. "Sewy" ranked to second highest length $(3.59 \mathrm{cms})$ but had the narrowest diameter (2.22 cms.). "Zahdi" and "Khalas" fruits ranked the third and fourth degree for both length and diameter $(3.47 \times 2.27$ and $3.40 \times 2.24 \mathrm{cms}$, respectively), while "Sakai" fruits were shortest in length $(3.13 \mathrm{cms})$ but ranked the second after "Medjool" in diameter $(2.33 \mathrm{cms})$. These results are generally in harmony with those reported by Hussein et al. (1976) on18 date cvs. grown in Saudi Arabia , Salem \&Hamdy (1993), Ahmed et al (1996) and Sayed(1999) on some Saudi and Iraqi date palm cultivars, Gadall (2013) on some Arabian date palm cultivars including "Zahidi", "Madjool", "Khalas" and "Sakai" as well as "Sewy" as local cultivar.

Data also revealed that as an arrange of two seasons flesh \% attained more than $90 \%$ of fruit weight in "Medjool" (93.18\% as average of the two seasons) and "Sewy" (92.92\%) fruits, while it was less than $80 \%$ in "Sakai" fruits (78.43\%). Meanwhile flesh \% was in between for "Zahdi" and "Khalas" cvs. (88.79 and 87.38\%, respectively). Mougheith et al (1976), Meligi et al (1983) and Abdallaet al (1995) reported that flesh \% varies according to cultivar. The available literature in this concern was reported by Khan et al., (2008) and Iqbal., et al., (2011). 


\section{Fruit chemical properties:}

Results presented in Table (5) indicated that there are significant differences in moisture content between the tested cvs. The average values of the two seasons show that moisture content of flesh was high in "Sakai" fruits (32.59\%) followed in a descending order by shoes of "Madjool" (28.85), "Zahdi" (26.04\%), and "Sewy" (24.90\%) then by fruits of "Khalas" which

attained the lowest moisture content (23.12\%). These results are in line with those obtained by Gadalla (2013) on some Arabian and local date cultivars, who found that the moisture content of fruits was ranged from 21.45 to $32.90 \%$ according to cultivar, also, Hussein et al., 1979 reported that moisture content in fruits of semi dry dates was ranged between 20 and $30 \%$.

\section{Total soluble solids (T.S.S)\%:}

Percentage of total soluble solids (T.S.S.) in the fruits significantly varied for the tested cultivars. Fruits of "Sakai"on the average attained the uppermost T.S.S.\% ( $71.35 \%$ ) against (50.30 \% ) for "Zahdi" cv. The other tested cvs. including "Sewy" cv. showed intermediate T.S.S. percentage. These results are generally in harmony with those reported by Abdalla et al. (1995) ; Ahmed et al (1996) and Sayed(1999) on some Saudi and Iraqi date palm cultivars.

\section{Total sugars, reducing sugars and non-reducing sugars content:}

As for total sugars, data in Table (5) reveal the same trends as observed for total soluble solids (T.S.S.), i.e. fruits of "Sakai" were had the highest content of total sugars ( $56.79 \%$ as average of the two seasons), descending followed by those of "Madjool" (55.44 \%) and "Sewy" (53.54\%) fruits, in comparison with both "Khalas" and "Zahdi" fruits which had the lowest total sugars content (42.23 \& $41.77 \%$, respectively). Results showed also that most of these sugars were found as reducing sugars. "Madjool" fruits were highest in reducing sugars content (47.94\%), followed by "Sewy" (40.53\%), "Sakai" (39.10\%) and "Khalas" (32.55\%) fruits, while "Zahdi" fruits were lowest in this respect (29.54\%). Data also showed that "Sakai" fruits came in the first rank between the tested cvs. in non-reducing sugars content (17.69\%), followed by "Sewy", "Zahdi" and "Khalas" (13.01, 12.24 and 9.68\%, respectively), while "Madjool" fruits had the lowest non- reducing sugars content (7.51\%). Analogical results were reported by Hussein et al (1976) on 18 date cvs. grown in Saudi Arabia, Habib et al (1984) and Hussein et al (1984) on some date palm cvs. grown in North and South Sina, Egypt, respectively. Also, Sayed (1999) on some Arabian date palm cvs. Including "Zahdi" and "Khalas" reported that there were significant variations in fruits content of total , reducing and non-reducing sugars among the date cultivars. 


\section{Tannins content:}

The average of the two years showed insignificant differences in fruit tannins content between the tested cvs. In general fruits tannins content was low in "Sewy" fruits (0.16 $\%)$, high in "Zahdi" fruits $(0.20 \%)$ and intermediate in the rest of tested cvs. The results are in harmony with those obtained by Sayed (1999) who reported that fruits tannins content ranged from $0.100 \%$ to $0.366 \%$ in some Saudi and Iraqi cvs. Ahmed et al., (1996) mentioned that total soluble tannins content in "Zahidi" fruits was 13.11 $\mathrm{mg} / 100 \mathrm{~g}$. of fresh weight. Khan et al., (2008) and Iqbal et al., (2011) they reported that physio-chemical properties of fruits were affected by cultivar and surrounding conditions.

\section{General evaluation and final conclusion:}

The numerical evaluation of Arabian date palm cultivars (Table 6) showed that "Medjool" seemed to be the superiors cv. in yield and fruit quality, as it attained the uppermost score units (98.22 units of 100 ) due to receiving all the units specified for yield and ranked the first position for three of the concerned 7 fruit properties i.e. fruit weight, flesh percentage and fruit length and ranked the second position for fruit diameter, total soluble solids and total sugars content. In other words, "Medjool" cv. ranked first in total score units of yield (30/30) and fruit quality (68.22/70).

local cv. "Sewy" occupied the second situation (87.15units/100) as it ranked the second in total score of yield (28.28/30 units) and receiving all the units specified for tannins content and ranked the second position for three properties i.e. fruit weight and fruit length and flesh percentage, it also ranked third position for two properties i.e., total soluble solids and total sugars content. In other words, "Sewy" cv. ranked the second position in total score units for yield (28.28/30) and fruit quality (58.90/70). "Zahdi" cv. ranked in the third position in the general evaluation (79.01/100) its ranking the third in total score of yield (27.77/30 units), however it occupied the lowest position in fruit quality (51.24/70) among all the tested cvs., the properties that reduced the score of fruit quality of this $\mathrm{Cv}$. were TSS, total sugars content and the high tannins content of fruit as well as the relatively low fruit weight. In other words, "Zahdi" cv. seemed to be of great yield but fruit quality was less than that of the standard studied cultivar ("Sewy"). 
Table 4. Fruit physical properties of some Arabian and local date cultivars grown under condition of Menofia government during 2014 and 2015 seasons.

\begin{tabular}{|c|c|c|c|c|c|c|c|c|c|c|c|c|}
\hline \multirow{2}{*}{ cultivars } & \multicolumn{3}{|c|}{ Fruit weight } & \multicolumn{3}{|c|}{ Fruit length } & \multicolumn{3}{|c|}{ Fruit diameter } & \multicolumn{3}{|c|}{ Flesh \% } \\
\hline & 2014 & 2015 & Av. & 2014 & 2015 & Av. & 2014 & 2015 & Av. & 2014 & 2015 & Av. \\
\hline Zahdi & 11.11 & 11.37 & 11.24 & 3.47 & 3.47 & 3.47 & 2.17 & 2.30 & 2.24 & 87.49 & 90.06 & 88.78 \\
\hline Sakai & 7.37 & 7.47 & 7.42 & 3.13 & 3.13 & 3.13 & 2.22 & 2.45 & 2.33 & 79.38 & 77.51 & 78.44 \\
\hline Khalas & 12.40 & 10.90 & 11.65 & 3.13 & 3.67 & 3.40 & 2.43 & 2.10 & 2.27 & 88.14 & 86.51 & 87.33 \\
\hline Medjool & 21.67 & 26.73 & 24.20 & 4.57 & 4.70 & 4.64 & 2.63 & 2.80 & 2.72 & 92.62 & 93.64 & 93.13 \\
\hline Sewy & 13.43 & 13.10 & 13.27 & 3.57 & 3.60 & 3.59 & 2.17 & 2.27 & 2.22 & 92.03 & 93.89 & 92.96 \\
\hline New L.S.D. at 0.05 & 1.75 & 2.19 & 1.97 & 0.37 & 0.34 & 0.36 & 0.23 & 0.28 & 0.26 & 1.71 & 1.49 & 1.60 \\
\hline
\end{tabular}


Table 5. Fruit chemical properties of some Arabian and local date cultivars grown under condition of Menofia government during 2014 and 2015

\begin{tabular}{|c|c|c|c|c|c|c|c|c|c|c|c|c|c|c|c|c|c|c|}
\hline \multirow{2}{*}{ cultivars } & \multicolumn{3}{|c|}{ Moisture content } & \multicolumn{3}{|c|}{ TS S \% } & \multicolumn{3}{|c|}{ Total sugars content $\%$} & \multicolumn{3}{|c|}{$\begin{array}{l}\text { Reducing sugars } \\
\text { content } \%\end{array}$} & \multicolumn{3}{|c|}{$\begin{array}{l}\text { Non-Reducing sugars } \\
\text { content } \%\end{array}$} & \multicolumn{3}{|c|}{ Tannins content \% } \\
\hline & 2014 & 2015 & $A v$. & 2014 & 2015 & Av. & 2014 & 2015 & Av. & 2014 & 2015 & Av. & 2014 & 2015 & Av. & 2014 & 2015 & Av. \\
\hline Zahdi & 26.37 & 25.70 & 26.04 & 45.73 & 54.87 & 50.30 & 44.37 & 39.17 & 41.77 & 31.2 & 27.87 & 29.54 & 13.17 & 11.3 & 12.24 & 0.20 & 0.20 & 0.20 \\
\hline Sakai & & 31.97 & 32.59 & 72.47 & 70.23 & 71.35 & 58.47 & 55.1 & 56.79 & 39.05 & 39.15 & 39.10 & 19.42 & 15.96 & 17.69 & 0.19 & 0.15 & 0.17 \\
\hline Khalas & 22.63 & 23.6 & 23.12 & 52.67 & 50.5 & 51.59 & 43.32 & 41.13 & 42.23 & 33.17 & 31.93 & 32.55 & 10.15 & 9.2 & 9.68 & 0.18 & 0.17 & 0.18 \\
\hline Medjool & 29.3 & 28.4 & 28.85 & 66.17 & 64.3 & 65.24 & 56.28 & 54.6 & 55.44 & 48.47 & 47.4 & 47.94 & 7.81 & 7.2 & 7.51 & 0.18 & 0.17 & 0.18 \\
\hline Sewy & 25.13 & 24.67 & 24.90 & 62.37 & 59.9 & 61.14 & 54.57 & 52.5 & 53.54 & 41.01 & 40.04 & 40.53 & 13.56 & 12.46 & 13.01 & 0.17 & 0.15 & 0.16 \\
\hline $\begin{array}{c}\text { New } \\
\text { L.S.D. at } \\
0.05\end{array}$ & 1.72 & 1.78 & 1.75 & 3.84 & 3.62 & 3.73 & 1.52 & 1.66 & 1.59 & 1.68 & 1.77 & 1.73 & 1.01 & 1.2 & 1.11 & N.S. & N.S. & N.S. \\
\hline
\end{tabular}


Table 6. Numerical of general evaluation of some Arabian and local date cultivars according to yield and fruit quality (average of two seasons).

\begin{tabular}{|c|c|c|c|c|c|c|c|c|c|c|}
\hline & & & & Fruit & quality (70 & & & & \multirow{3}{*}{$\begin{array}{l}\text { Total score of } \\
\text { fruit quality (70) }\end{array}$} & \multirow{3}{*}{$\begin{array}{c}\text { General } \\
\text { evaluation of } \\
\text { palms (100) }\end{array}$} \\
\hline & \multirow{2}{*}{$\begin{array}{l}\text { Per palm } \\
\text { Units (30) }\end{array}$} & 15 & 15 & 5 & 5 & 10 & 15 & 5 & & \\
\hline Cultivars & & $\begin{array}{c}\text { Fruit } \\
\text { Weight }\end{array}$ & Flesh \% & Fruit length & $\begin{array}{l}\text { Fruit } \\
\text { diameter }\end{array}$ & TSS & $\begin{array}{l}\text { Total } \\
\text { sugars }\end{array}$ & Tannins & & \\
\hline Zahdi & 27.77 & 7.0 & 14.30 & 3.74 & 4.12 & 7.05 & 11.03 & 4.00 & 51.24 & 79.01 \\
\hline Sakgey & 11.87 & 4.60 & 12.63 & 3.37 & 4.28 & 10.00 & 15.00 & 4.71 & 54.59 & 66.46 \\
\hline Khalas & 15.99 & 7.22 & 14.07 & 3.66 & 4.17 & 7.23 & 11.15 & 4.44 & 51.94 & 67.93 \\
\hline Medjool & 30.00 & 15.00 & 15.00 & 5.00 & 5.00 & 9.14 & 14.64 & 4.44 & 68.22 & 98.22 \\
\hline Sewy & 28.28 & 8.23 & 14.97 & 3.87 & 4.09 & 8.57 & 14.14 & 5.0 & 58.87 & 87.15 \\
\hline
\end{tabular}


"Khalas" cv. received 67.93 units/100 as general evaluation, it ranked the fourth in total score of yield (15.99/30 units) i.e. more than $75 \%$ of general score is mainly due to fruit quality (51.94 units), which was generally lower than of "Sewy" cv. (58.87), the properties that reduced the score of fruit quality of this $\mathrm{cv}$. were the relatively low fruit weight, TSS, total sugars content and the relatively high tannins content of fruit.

"Sakai" cv. occupied the last position among the tested cvs. due to its receiving the least general evaluation (66.46units/100), due to receiving the least units specified for yield (11.87/30). This may be due to its lowest number of bunches / palm, fruit weight and fruit retention \%. It is worth mention that, more than $80 \%$ of general evaluation score is mainly due to fruit quality

(54.59 units). Fruits of "Sakai" cv. had the highest TSS, total sugars and lower tannins content among the tested cultivars.

Thus, one can conclude that"Medjool" and "Sewy" cvs. proved to be the superior cvs. in yield and fruit quality among all the tested cvs. However "Zahdi" cv. seemed to be of great yield but fruit quality was less than the standard studied cv. ("Sewy"). On the other hand,"Sakai "cv. showed less palm yield but fruit quality was reasonable for consumer, but it was generally lower than of "Sewy" cultivar.

\section{REFERENCES}

1. Abdalla, M.Y.; M.B. Bastawros and L.F.Haggag. 1991. Effect of planting zone on bunch and fruit properties of Samany dates. Zagazig J.Agric. Res. 18 (1):135143.

2. Abdalla, M.Y; A.A. Abdel-Aal and A.M. Abd-Elkader. 1995. Evaluation of some local date palm cultivars grown in the Northern part of the Delta, Egypt. Zagazig J. Agric. Res. 22 (4): 1065-1076.

3. Ahmed, F.F., EIMalt, E.A.; Ragab M.A. and Gobara A.A. 1996. Comparative study of productivity, some physical and nutritional characteristics of thirteen Saudi and Iraqi date palm cultivars (Phoenixdactylifera L.) grown under middle Egypt conditions. Annals of Agric. Sci. Moshtohor 34 (4) 1809-1833.

4. A.O.A.C. 1995. Official Methods of analysis. 16th Ed. Published by Association of Official Agricultural Chemists, Washington, D. C. (U.S.A.).

5. Brown, W. and M. Bahgat 1938. The date palm in Egypt. Ministry of Agric., Hort. Section, Giza, Egypt, Booklet No.24, 117pp.

6. Gadalla, E.G 2013. Behavior study of some Arabian Date Palm Cultivars Produced through Tissue Culture grown under Al Saff region - Giza Governorate.Egypt J. of Appl. Sci., 28 (8):436-453. 
7. Habib,S.S.; N.M. El-Gamal; G.M. Nour and A.A. Hussein. 1984. Evaluation of some date palm varieties grown in North Sinai governorate. Agric. Res. Rev. 62 (3A) 277288.

8. Hussein, F., S. Moustafa; A. El-Zeid and F. El-Samiraea. 1976. Studies on physical and chemical characteristics of eighteen date cultivars grown in Saudi Arabia. Indian J. Hort. 33 (2) June.

9. Hussein,A.A.; N.M. Gamal; G.M. Nour and S.S. Habib. 1984. Evaluation of some date palm varieties grown in South Sinai governorate. Agric. Res. Rev. 62 (3A) 289-303.

10. Khan, R.U.; Rushid, A. and Khan, M.S. 2008. Evaluation of date palm cultivars with their monetary returns under ecological zone of Dera Ismail Khan . J. Agric. Res. 46 (1) 93-98.

11. Iqbal, M.; Imranullah, M. and Niamatullah, M. 2011. Physio-chemical characteristics of

12. date palm (phoenix dactyliferal.) cultivars at various maturity stages under environmental conditions of Dera Ismail khan. J. Agric. Res., 2011, 49(2).

13. Meligi, M.A., G.F. Sourial, A.M. Mohesen, A.S. Khalifa and M.Y. Abdalla. 1983. fruit quality and general evaluation of some Iraqi date palm cv. grown under conditions of Barrage region, Egypt. The first symposium on date palm in Saudi Arabia, March $23-25,1983$.

14. Mougheith, M.G., I.A. Hasaballa and M.A. El- Ashrum. 1976. Comparative studies on fruit development, quality and bunch characteristics at harvest of some Egyptian date palm cultivars. Annal of Agric. Sci. Moshtohor (5):179-193.

15. Resenabatt, M. and J. V. Pluso. 1941. Determination of tannins by spectrophotometer. J. Asso. Offic.Agr. Chemists, 24: 170.

16. Salem, M.S. and Hamdy, Z.M. 1993. Evaluation of some Iraqi date cultivars under condition of Upper Egypt. Egypt J. Applied. Sci. 8 (5): 250-269.

17. Sayed, S.M. 1999. Evaluation of some date palm cultivars grown under El-Minia region condition.M.Sc. Thesis Fac. Agric. El-Minia Univ.

18. Sendecor, G. W. and W. G. Cochran. 1980. Statistical Methods. Oxford and J. B. H. publishing Com. 6th edition.

19. Waller, R. A. and D. B. Duncan. 1969. A buyes rule for the symmetric multiple comparision proplems.Amer.state.Assoc.J.,64:1484-1503

20. Zaid, A. 2002. Date Palm Cultivation. FAO Plant Production and Protection Paper no. 156. 


\title{
دراسة مقارنة لبعض أصناف نخيل البلح العربية النصف جافة النامية بمحافظة المنوفية
}

\author{
سامية صلاح الدين حني \\ قسم بحوث الفاكهة الآستوائية - معهُ بحوث البساتين - مركز البحوث الزراعية- مصر
}

أجري هذا البحث خلال الفترة من ع ا ـ ب الي 0 ـ ب لار اسة مقارنة لبعض أصناف النخيل

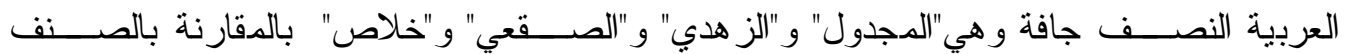

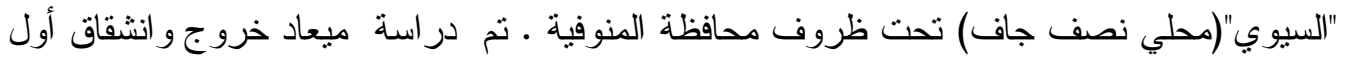

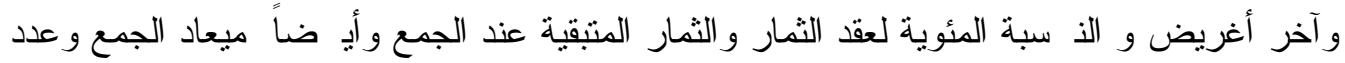
السوباطات و المحصول لكل نخلة وكذلك الصفات الطبيعية و الكيماوية للثمار للأصناف المختبرة. وقد أظهرت النتائج أن خروج و أنشــقاق الأغاريض كانت مبكرة في صــنفي "المدجول" و "الخلاص"

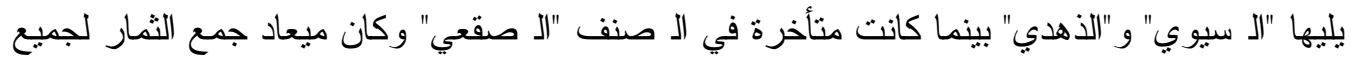

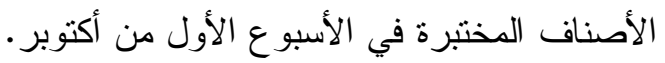

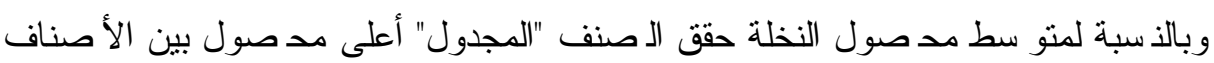
المختبرة يليه "الـ سيوي" ثم "الذهدي" بينما كان أقل مد صول في صنفي "الـ صقعي" و "الخلاص". وقد

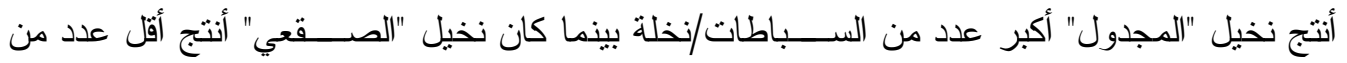

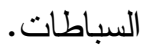

أما نسبة عقد الثمار و الثمار المتبقة عند الجمع ، أعطى الصنف "مدجول" أعلى قيم من ذسبة العقد و الثمار المتبقية في حين كان الصنف "خلاص" اقلهم في هذا الثأن. وتفوقت ثمار الصـــفتهدجول" في الوزن و الأبعاد ونســـبة اللحم لوزن الثمرة بينما ثمار "الصقعي" كانت أقلهم و أحتوت ثمار الصنف "الصقعي" أعلى محتوى من الرطوبة بينما ثمار الصنف لونف

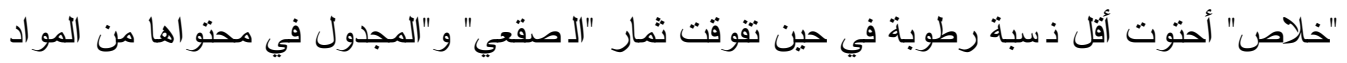
الصلبة الكلية و السكريات الكلية. وأن محتوى الثمار من النتانينات أختلفت فيما بين الأصناف المختبرة ولكن هذه الأختلافات لم تكن معنوية.

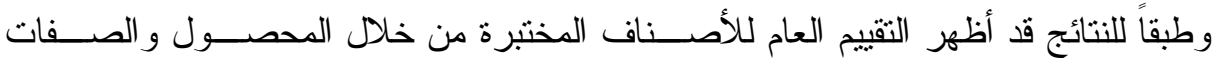
الثمرية أن الصنفي "مدجول" و"السيوي" تفوقا في المدصول و الصفات الثمرية بينما الصنف "ذهدي"

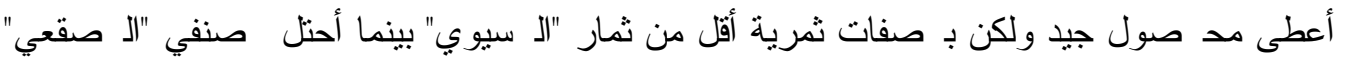

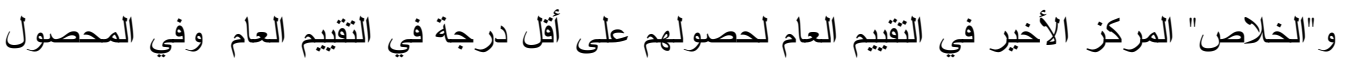
بينما كانت الصفات الثمرية لنمار "الصقعي" مقبولة للمستهلك وأن كانت أقل من ثمار "السيوي". 